\title{
POLITICAL AND SOCIAL PARTICIPATION OF ITALIAN WOMEN IN THE EUROPEAN CONTEXT
}

Edi PUKA, PhD

Associate Proffessor, European University of Tirana, Albania edi.puka@uet.edu.al

Dilina BESHIRI, PhD

University “A. Moisiu” Durrës, Albania dilina_b@hotmail.com

\begin{abstract}
Politics is a field in which the female presence is still very scarce; however, women having attended political positions, as head of governments, have left their marks as to be nicknamed iron ladies. The relationship of women with politics continues to be discussed and is increasingly addressed as a democracy rather than women problem. Although the Italian women have acquired political rights in the last century, they have not been able to participate to a large extent in representative political institutions. The purpose of this article is to analyze the reasons for this phenomenon, and whether it is linked to representation crisis and sociocultural factors. It is a question of raising public awareness on this issue, and of changing a political culture which even today considers man to be the legitimate protagonist of the State management.
\end{abstract}

Keywords: Italian women; politics; leadership; vote; human rights.

\section{Introduction}

Despite the fact that in recent years the women's political participation has undergone significant changes both in terms of quantity and quality, several studies continue to emphasize 
that the relational network of men still remains not only more extensive than that of women, but also of a stronger political importance.

"The sociological cut allows - thanks also to the amplitude of the examined and proposed material in the context of a problem that remains open, without ideological constraints and without conclusive answers - a careful approach to the current situation as it emerges in today's political affair with its debates, its conditioning, as well as its disappointments. In the base of this claim there is more than a sacrosanct legitimate subjective right: there is the utopia of recomposition, in the collective political project, of the spheres of interests of humanity, the recognition of the historical-political value for the design of the future, demographic and affective problems, daily well-being and life organization”. (Nicola, 1983, p. 11)

Given the lower level of political information and a limited sense of effectiveness, the inclusion in groups and organizational structures, even if not specifically political, increases for the women the sense of security in the affirmation of their opinions and stimulates their political participation from voting to active commitment. The greater dependence on political intermediaries would be the consequence of a low confidence in their ability to elaborate autonomous political opinions and of the need to be reassured. This need for reassurance, which often comes from groups and organizations still dominated by male figures, highlights the persistence of the so-called "independence gap".

The issue of the absence of female presence in many positions of political decision-making is a fact that, sixty years after the acquisition of electoral rights by women, constitutes the symptom of a defeat for democracy itself. It leaves open the problem of rebalancing the representation and accomplishing an effective and not halved democracy. Furthermore, concrete measures are needed to be taken in order to promote the political participation of women. Firstly, the electoral system of a majority type tends in itself to exclude minor political forces such as, for instance, the young people, who are today on the margins of politics. In the basic political structures, such as parties and unions, with the women not being present to a considerable extent, a female political movement, capable of constituting itself as a point of reference for the female voters as well as the elected ones, has not been formed yet. In addition, the absence of women in primary party 
organizations deprives the candidates from the moral and political support during the election campaign.

The contact with realities such as school, hospitals, parish, acquired during the personal experience of a daughter, wife and mother, has given the women a singular ability to analyze the society, to understand the problems and often successfully try to solve them. By showing a strong sense of civic responsibility, women have chosen other political locations to operate.

\section{The feminist movement and political representation in Europe}

"Feminism was the first form of public identity movement started by women, at first as a fierce minority, then in increasingly extended groups, since the end of 1600”. (Aistone \& Spence: 2010)

At that time, a fierce dispute about the abilities and social role of women was initiated. The problem was on the agenda: economic, social and political transformations had laid the foundations for a broader and more conscious participation of women in the political, artistic and cultural life. Yet many of them still led a wretched and mortifying life, excluded from the high levels of education as well as from every significant role, surrendered to natural life during or through marriage or seclusion.

But we must historically wait for the French Revolution (1789) to find out significant documents related to the image of woman. Thus we find in France Olympe de Gouges (1748-1793) with her "Declaration of the Rights of Woman and the Female Citizen" of $\underline{1791}$. The intent of the Declaration was to make women aware of the rights denied to them and then to ask for their reintegration in order to make women become citizens in every respect. The woman - is stated in the Declaration - is born free and has the same rights as the man. Social distinctions can only be based on common utility (art.1) (Santucci, 2004, p. 42); as natural rights are considered freedom, property, security and above all resistance to oppression (Article 2); all the female citizens must be admitted to every public dignity, position and employment, based on their abilities and without other distinctions compared to those of their virtues and talents (art.6); the woman must be free to express her thoughts and opinions (art.11). (Martino \& Bruzzese, 1994, p. 181)

In England, just in the same period, there is Mary Wollstonecraft (1739-1797), author of a work entitled "Claiming the rights of women" (1792), which intends to place the demands for liberation and social and political equality women in the context of the more general enlightening program of human rights. Women must leave their golden cage of "femininity", which constitutes 
the other side of marginalization and subordination; the woman must acquire the ideal of reason, addressing her own sex; no more seductive lovers, but "affectionate mothers and rational mothers". Women must be fully involved in the enlightening and reformist project: education, political rights, personal responsibility, economic equality, rationality and virtue, freedom and happiness. These are the ideals of Wollstonecraft, who also comes to provocatively propose a female demystifying "chastity" of ambiguous relations with man. The female mind has been relegated from male tyranny into a limbo of fatuity to which women, for the most part, have adapted themselves. But women nowadays must know that the rights they claim correspond to duties and that rebellion against male domination must take place in the name of universal values, such as those emerging from modern thought. Intellect, virtue and freedom are the three faces of enlightened reasoning, laid down by Wollstonecraft as principles of her thought. Her goal is the creation of a "new civilization", in which humanity is virtuous and happy. (Wollstonecraft, 1977, p. 78)

In Italy, the women's rights movement was born lagging behind other countries. When the industrial revolution started to include women as a labour force, problems such as working hours arose, in order to be reconciled with housework, as well as the protection of motherhood. Thus, female groups were formed, which at first were mostly formed by women of the bourgeoisie. Later on, movements of socialist women also joined them. Anna Maria Mozzoni, with her autobiographical book “A woman and Anna Kuliscioff”, was among the pioneers of women's rights movement.

The real feminism will only come into being only in the nineteenth century. The ethicalpolitical horizon of nineteenth-century feminism has been that of egalitarianism between sexes and the legal and economic emancipation of women. During the nineteenth century, feminists have committed themselves both on specific objectives as well as on issues concerning human and civil rights in a broad sense: struggles for freedom of thought and association, for the abolition of slavery and prostitution, for peace. Another thing to note is that the feminist movement has coexisted with the socialist movement since the beginning of the nineteenth century.

In the second half of the nineteenth century, the political sign of feminism changed as a result of urbanization and industrialization processes taking place both in Europe and in the United States. Not only learned and highly educated women, but also women among working class and petty-bourgeoisie were involved by the socialist and feminist movements who finally identified a specific strategy to address the "female question". 
In the United States there was Lucretia Coffin Mott (1793-1880), a social reformer and "Quaker" preacher, working on the issues of the abolition of slavery, of the election right for women and of peace in the world. In England, the National Society for Woman's Suffrage, led by Lydia Becker, and the Ladies National Association of Josephine Butler, were also committed to regulation if not abolition of prostitution.

In France, we can remember Hubertine Auclert (1848-1914), who proposed a salary for housewives in 1879 and promoted a women's tax strike up until granting of the right to vote. In 1904, she became protagonist of a news story that made her even more famous: in the course of yet another feminist event, she tore up a copy of the Napoleonic Code, which anniversary was celebrated in those days, for its unfair provisions, according to Auclert, in the field of private law.

But we must wait for the mid-60s of this century, when the Women's Liberation Movement was born as an expression of contradictions of the female social role in the countries of advanced capitalism (Europe and USA): economic insertion at low levels of the system, exploitation of domestic work, consumer use of female image, repressive education, extraneousness of women to traditional political parties, need for new values. During this period, precisely in 1963, in the United States appeared an essay written by Betty Friedan, "The Mysticism of Femininity" (Betty Friedan, 1963), where she claimed that the American society had reached the point of maximum tension between the reality of female life and the woman image proposed by mass media and official culture. According to Friedan, starting from the 1940s, a "mysticism of femininity" was proposed, that is, a model of organic and closed life and happiness: love, children, husband, home, shopping, clothes, etc., that finally was falling into a crisis.

The debate was enriched in 1969 with the publication of "The politics of sex" by Kate Millet (Millet, 1979). With this book, the specifically radical trend of new feminism was inaugurated, a sexist and separatist tendency that eventually combined cultural and literary analysis, the program of a radical opposition against a society intended primarily as a masculine and patriarchal one. Millet explicitly made the action of Feminism a struggle against a power for another and different power. Thus, the aim of the movement was no longer that of equality, but of excellence of the woman, of her superiority: it was a feminism of difference, a feminism that was to be qualified above all as an intellectual movement. Twenty years after the first street demonstrations and winning struggles on divorce and abortion, feminism is still alive, even if it has been transformed into the culture and political reflection of women. (De Leo 1999, p. 265) 
Radical feminism has become, in fact, since the 80 s, a feminism of complexity, a systemic feminism. But the fact of its having become a cultured, in some respects esoteric feminism, does not constitute the only transformation. Out of a mass social movement, it has become a network of small groups: this has allowed a refinement of the theoretical elaboration, but it has probably lost positions on the political level, while the "rights of women" have become a sort of commonplace of the political agenda for all parties.

The ultimate challenge attempted by the women's political movement in Italy - of which the National Feminine Union represented the most articulate and mature expression - was to consciously assume the partiality of a subject excluded at every level from the totality of a project of change - the women - as a universal measure and paradigm of transformation.

Such a prospect would have been sustainable, but only if the woman had been prepared to live as an autonomous subject that did not take the male meter to check her role in the world, but would simply measure her own self. (Buttafuoco, 1992, p. 27).

\section{Women in Europe: the tools of women's politics}

To examine the role and position of European women in political institutions, a brief historical reference should be made starting with the acquisition of the right to vote, as the female political history in this context is recent. At the end of the $18^{\text {th }}$ century, European women did not enjoy civil or political rights, granted only to restricted sections of the population.

In fact, before obtaining the right to vote and eligibility on cantonal and federal level, women could express their political commitment only in the context of women's organizations and professional associations. In some countries, they could also take part in school commissions, commissions for public assistance, ecclesial and parish councils and in some other political authority. Even the first women holding municipal or regional political offices at the turn of the 1960s and 1970s had been active in such forums before trying to reach the big public stage.

In 1971, when women finally entered federal politics, they also began their advance into party functions, in parliaments, in the executive and other political offices. In European comparison, the women's presence in the National Council, with $23.5 \%$ of the votes achieved in the federal elections of 1999, is actually in the median band: higher percentages are to be observed in the Scandinavian area and in the Netherlands (between 36\% and 42.7\%), as well as in Germany (30.9\%), Spain (28.3\%) and Austria (26.8\%). Despite the progress made and although the women 
constitute the majority of resident population and electorate, the Swiss women are still decidedly underrepresented at all political levels.

The Nordic countries are all among the top ten in the ranking: in the last five years, the first 4 positions are constantly held by Iceland, Norway, Finland and Sweden ${ }^{1}$, while Denmark is in $7^{\text {th }}$ place. The first 4 countries are among the top 20 in the sub-index of participation and economic opportunities and again get the first 4 places in the sub-index of political participation. In the Nordic countries, in fact, female labour force participation is among the highest in the world and the wage differences compared to men are among the lowest in the world, even though full pay equality has not yet been achieved. The policies of these countries include mandatory paternity leaves in association with generous maternity leaves, incentives and post-maternity programs of re-entry. In some countries, a leave can also last a full year: in Norway, the leave lasts 46 weeks with an allowance equal to $100 \%$ of the salary, or 56 weeks with $80 \%$ of the salary; in Sweden, the leave lasts 480 days, with an allowance calculated on salary basis for the first 390 days (80\% of the salary, within a maximum limit) and a fixed allowance in the last 90 days; in Denmark, it lasts 52 weeks to $80 \%$ of the salary (with a maximum ceiling).

Icelandic post-maternity re-entry programs have strongly contributed to positioning the country in first place in the Global Gender Gap Index: in Iceland, it is the legal right to return to work after the child birth and a capillary system of nurseries and kindergartens is offered by the main municipalities. Women also have many opportunities to achieve positions of power, partly because the Nordic countries have adopted policies to promote female leadership. Regarding women's participation in politics, the Nordic countries were among the pioneers of women's right to vote $^{2}$, and in the 1970s the Norwegian, Swedish and Danish political parties introduced voluntary quotas, with a consequent increasing in political participation of women. Actually the figures of women's participation in politics in the Nordic countries are among the highest in the world, both in terms of percentage of women in parliament (45\% in Sweden, 43\% in Iceland, 40\% in Norway and Finland, 38\% in Denmark), as well as concerning the number of women in the

\footnotetext{
${ }^{1}$ Listed in the order in which they appear in the Global Gender Gap Index of 2010.

${ }^{2}$ The right of women to vote was ratified in 1906 in Finland, in 1913 in Norway, in 1915 in Iceland and Denmark, in 1919 in Sweden.
} 
position of ministers (63\% in Finland, 53\% in Norway, $45 \%$ in Sweden and Iceland, $42 \%$ in Denmark).

Tab. 1 - World ranking of female presence in national parliaments

\begin{tabular}{|c|c|c|c|c|c|c|c|c|c|}
\hline \multirow{2}{*}{ Rank } & \multirow{2}{*}{ Country } & \multicolumn{4}{|c|}{ Lower or single House } & \multicolumn{4}{|c|}{ Upper House or Senate } \\
\hline & & Elections & Seats & Women & $\% \mathrm{~W}$ & Elections & Seats & Women & $\% \mathrm{~W}$ \\
\hline 1 & Rwanda & 92008 & 80 & 45 & $56.30 \%$ & 102003 & 26 & 9 & $34.60 \%$ \\
\hline 2 & Sweden & 92010 & 349 & 157 & $45.00 \%$ & --- & --- & --- & --- \\
\hline 3 & South Africa & 42009 & 400 & 178 & $44.50 \%$ & 42009 & 54 & 16 & $29.60 \%$ \\
\hline 4 & Cuba & 12008 & 614 & 265 & $43.20 \%$ & --- & --- & --- & --- \\
\hline 5 & Iceland & 42009 & 63 & 27 & $42.90 \%$ & --- & --- & --- & --- \\
\hline 6 & Netherlands & 62010 & 150 & 61 & $40.70 \%$ & 52007 & 75 & 26 & $34.70 \%$ \\
\hline 7 & Finland & 32007 & 200 & 80 & $40.00 \%$ & --- & --- & --- & --- \\
\hline 8 & Norway & 92009 & 169 & 67 & $39.60 \%$ & --- & --- & --- & --- \\
\hline 9 & Belgium & 62010 & 150 & 59 & $39.30 \%$ & 62010 & 71 & 27 & $38.00 \%$ \\
\hline 10 & Mozambique & 102009 & 250 & 98 & $39.20 \%$ & --- & --- & --- & --- \\
\hline
\end{tabular}

Source: Inter-Parliamentary Union: http://www.ipu.org/wmn-e/classif.htm

Recently, the issue concerning the political participation of women has become very current; the EU has undertaken a series of initiatives (polls, surveys, declarations of principle, legislative initiatives), also involving individual national governments, but women still continue to be underrepresented in positions involving political and economic responsibilities, even if the percentage has increased during the last ten years. The rate of women's employment, although growing, has yet to increase in order to reach the target set by the Europe 2020 strategy.

\section{History of Italian Women in the $20^{\text {th }}$ century}

In Italy, women's long journey towards equality and full political citizenship embraces the period extended from the country's unification to the present day, i.e. from the conquest of the right to vote to the most recent policies of equal opportunities. The struggle for gender equality in Italy took place later than the rest of the European Union. 
In the young Italian Republic, women were, in fact, excluded from both political and administrative voting rights. Nevertheless, prominent figures such as Anna Maria Mozzoni denounce the situation of limited citizenship imposed by the Italian State on its own female citizens. Between the end of the $19^{\text {th }}$ century and the beginning of the $20^{\text {th }}$ century(Morandini, 1988, p. 177), some newly established organizations get involved in the issue of civil and political rights (The National Association for the Woman, The National Women Union, The National Council of Italian Women, The Women's Alliance, the National Committee for Suffrage). The bill for women's voting rights in the life of the Italian Republic will be twenty, but until the World War II none of these will be approved and sometimes not even discussed.

The advent of fascism had heavy repercussions on the women citizenship: in 1925, with the Acerbo Law, the right to vote for some categories of women was granted, but soon after the establishment of the mayoral regime, the recognized rights were cancelled. Many associations were dissolved, while others survived only under the regime control or emptied of any political significance. Fascism promoted an active policy towards the female universe and outlined a specific social figure for women; it braked the participation in the labour market (women's wages were set by law to half of men's, and they were progressively excluded from some careers) and the women's activity was limited within domestic walls through demographic policy, the Family Code and the new Criminal Code.

The Second World War is whiteness of a new female protagonist in the Resistance. In January 1945, the Council of Ministers issued the decree recognizing the right to vote for women who had completed their twenty-first years of age on December 31, 1944. In the Constituent Assembly we find 21 elected women and in the Constitution was established the principle of gender equality (articles 3, 4, 37, 29, 51), with some exceptions regarding the family institution (articles 29, 30, 31 and 37), in which the priority role of women is reconfirmed.

Italy experienced the first female suffrage experiment on June 2, 1946, when 13,354,601 men and 14.610.845 women were called to vote for the Constituent Assembly. Contradicting those who expected women not to exercise their new right, 12.998.131 female against 11,949,056 male voters went to the polls. On that occasion, the percentage of female voters reached the figure of 89.1\%. But if women's political participation started in 1945 with their acquisition of active and passive political rights, women's accession to politics and their intervention within the parties is noted already earlier. (Bagnato, 2006, p. 56) 
In the immediate post-war period, the objective of giving women the right to vote was included in the program of the Italian Popular Party. Furthermore, it must not be forgotten that in the National Council of the party there was a female representative already since its foundation.

Later on, with the beginning of democratic life, beside the right to vote, the woman acquired the right to be elected in municipal and provincial councils and in parliamentary assemblies. All the parties welcomed women as their members and different treatments were granted to them from a party to another.

The Communist Party, in the article 4 of the first post-World War II statutory paper, stated the following related to the political cellule structure: "The women enrolled in the party can be organized in mixed or female cellules both at work and at home". Subsequently the statute was modified with the words: "only in exceptional cases, the constitution of female cellules is allowed".

Subsequently, however, there was no longer talk of women's movement, but only of female activities that could be expressed through provincial commissions and a national commission. (Bagnato, 2006, p. 96)

During the 1940s, new work benefits became available to women, including maternity leave, daycare, and counseling. These benefits developed more substantially in Europe, as many countries there were devastated by war, where much of the male population was reduced. (Castledine \& Laughlin, 2011, p. 4). On June 2, 1946, after the institutional referendum and the constituent assembly elections, the Italian women exercised for the first time the right to political vote.

The period after World War II sees the first woman named in a government. The practical realization of equality principle between the sexes was achieved after years of hard struggles by women.

Only in 1963, the law was passed admitting the women's competing to become a part of the judiciary and in 1965 appear the first female judges. Also, in 1963, the law prohibiting the dismissal due to marriage was voted.

In the 1970s, the second wave feminist movement expanded and continued to gain momentum. Carol Hanisch published an essay in 1970 titled "The Personal is Political." Hanisch argued that everything was political, including division of household labor, gender roles, and other day-to-day activities. If a woman decided to have an abortion and get a job as a woman in a male dominated 
industry, then that decision has political consequences and became politicized in society. Women had to bring their private, household problems into the public sphere because issues were politicized and had consequence far outside of an individual (Man Ling, 2007).

During the 70s, in Italy, following the emerging on the public scene of female and feminist movements, divorce was introduced, the Family Law was reformed ensuring legal equality between spouses, and voluntary termination of pregnancy was legalized. In 1977, the law of parity was approved, amended in 1991 by the new legislation on equal opportunities (Law, 125), providing for positive actions as an instrument for overcoming inequalities. Since the Unification of Italy onwards, the presence of women had been particularly significant, and as expressed by them, the Italian women had exercised their intelligence, talents and feeling capacities: education, work, charity (Italian Women Committee, 1904).

Just in the 80 s, in fact, in Italy there was the start of institutional policies in favour of women. Central and local equality bodies have been set up; the presence of women in institutions grew. And we cannot forget the profound change in society due to the emerging of the values and culture of women. This change has produced a diverse way of conceiving the relationships between sexes, and for women, it has favoured the acquisition of "self-awareness": a process made possible even by the massive inclusion into the world of labour. (Cappiello, 1999, p. 17)

In this period, the community legislation accompanies the national legislation, which often anticipates the issues subsequently taken into consideration at state level. Political representation and presence of women in decision-making processes is one of the fronts of greater debate. In 1993, Italy moved from proportional to majority system and the mandatory quotas for male and female applications were approved (Law 125/91). The Constitutional Court however, with the sentence No 442 of 1995, declares such norms as illegitimate. In 1996, the alternation of male and female candidates on electoral lists in Italy was abolished; this provision, added to the adoption of a mixed majority voting system, negatively influenced the political participation of women.

In reality, despite the undoubted successes in the grown presence of women in institutions, work and cultural life, if only we consider, among others, indicators such as the presence of women in the seats of economic and political decisions, we come to realize that gender equality is far from being acquired. In all the working sectors, in fact, men tend to occupy positions of greater power and status; in organizations, the top management positions are mostly occupied by men, and in the political institutions the number of women is constantly lower than that of men. 


\section{Female representation in the Italian Parliament}

A more articulate and not foregone reflection on the meaning of women's political representation in Italy today also allows us to better understand data and statistics. In this section, I will present some empirical research results with the aim of reconstructing the meaning of women's presence in the Senate and Chamber of Deputies since 1948 (year of entry into force of the Republican Constitution) to date, trying to trace biographical and political characteristics in the phenomenon.

Although women acquired political citizenship in 1946 and thus obtained the right to elect and be elected, their presence has nevertheless remained proportionally limited in spite of its growing over the decades.

In 1946, only 21 women were elected to the Constituent Assembly, or 3.77\% of the members. In 1948, with the entry into force of the Constitution and the election of a regular parliament divided into two branches, the female senators were found to be $1.27 \%$, while the female deputies amounted to $6.19 \%$. The historical lows were reached in the Senate in 1953 with $0.32 \%$, while in the Chamber of Deputies in 1968 with 2.7\%. 60 years later, in 2008, the female senators rise to $18.32 \%$, while the deputies are at $20.95 \%$.

To date, $51.6 \%$ of Italians are women. $52 \%$ of the voters are women. These data contrast with the lack of women's presence in both national and local representative assemblies and above all, with the great role women have assumed in Italian society in the field of labour, professions, education, also excelling in sectors that until a few years ago they were the exclusive domain of men.

This reduced level of female participation in the case of Italy constitutes a pathology of the representative system, which in the past has not been dealt with sufficiently. In fact, the proportion of female parliamentarians has never diverged much from $10 \%$ and the regulations passed in the early 1990s, in an attempt to heal this gap, were annulled by the Constitutional Court, because they were found in contrast with the principle of formal equality of citizens in the field of active and passive electoral rights. In the last legislature, a bill of a parliamentary initiative, to change the Constitution in this matter, did not go beyond a first reading by the Chamber.

On this subject, in July 2001, a constitutional bill was approved for the amendment of article 51 of the Constitution concerning access to elective offices and public offices. This is a preparatory 
and fundamental step for any legislation supporting female representation, because it aims to create a "constitutional umbrella" for positive actions in favour of the women.

The "new" article 51 of the Constitution became a law on May 30, 2003. In the "old" text, at the end of the first paragraph, was added the sentence: "The Republic promotes with equal provisions equal opportunities between women and men", affirming not only the right of all citizens of both sexes to access, in conditions of equality of law and fact, to public offices and elective offices, but also the constitutional "mission" to promote the rebalancing of representation.

This is an issue that Italy wished to be focal also during its presidency of the European Union, in the second half of 2003, dedicating thus to "Women in political and economic decision-making processes" the great event and ministerial conference on equal opportunities. On that occasion the EU ministers approved a document defining as a common political objective that of having in the various countries of the Union a share of female candidates that would be never less than one third. This was an objective to pursue especially in countries where political practice was not already consolidated at a more favourable extent for women, through means including constitutional and regulatory interventions. In fact, the Government's project for women developed during 2004 with the modification of the article 51. This includes initiatives concerning an electoral, as well as social and cultural level.

The first national electoral consultation scheduled after the approval of the constitutional amendment was that concerning the renewal of the European Parliament. And it is on that occasion that under the bill on the so-called "election day", a provision was approved by the Council of Ministers and therefore by the Parliament that introduced the obligation for parties to reserve no less than one third of the candidates for the less represented gender. The measure is temporary and applies to the two European electoral cycles following the approval of this provision.

The violation of this provision is punished by a reduction in the amount of reimbursement of electoral expenses, up to a maximum of half, in direct proportion to the difference of number of candidates considering the maximum allowed for each gender. This law, applied for the first time in the European elections last June, led to the doubling of female candidates, which were about $35 \%$ of the total, and a substantial increase in the number of elected candidates, which rose from 11 to $19 \%$ of Italian representatives in Strasbourg.

Female representation in the Italian Parliament, although decidedly minor, has strengthened in the last legislature (XVI): in the Chamber of Deputies women are equal to 21.27 of the elected 
members while in the Senate of the Republic female senators represent $18.3 \%$ of the assembly. Such quotas are absolutely the highest in the parliamentary history for both chambers, and reverse the negative trend of the decrease of female representation in the Parliament produced during the 90s, after the peak recorded in the twelfth legislature.

The data acquire additional positive value considering the distribution of the elected by age group. In fact, relations between gender representations are less unbalanced in favour of men in the younger classes (25-29 and 29-39 in the Chamber and 40-49 in the Senate); this figure, also considering the strong rate of re-election in successive legislatures characterizing the country, would suggest a further consolidation of shares of the elected women even in the older classes, during the course of future legislatures ${ }^{3}$.

Tab. 2 - Women senator from $1^{\text {st }}(1948)$ to the $16^{\text {th }}$ (2008) Legislature

\begin{tabular}{|c|c|c|}
\hline \multicolumn{3}{|c|}{ THE WOMEN IN THE ITALIAN PARLIAMENT } \\
\hline LEGISLATURE & CHAMBER (\%) & SENATE $(\%)$ \\
\hline COSTITUENT 1946-48 & 4,1 & \\
\hline 1^ LEGISLATURE 1948 & 6,7 & 1,1 \\
\hline $2^{\wedge}$ LEGISLATURE 1953 & 5,5 & 0,4 \\
\hline 3^ LEGISLATURE 1958 & 3,6 & 1,2 \\
\hline $4^{\wedge}$ LEGISLATURE 1963 & 4,6 & 1,8 \\
\hline 5^ LEGISLATURE 1968 & 2,6 & 3,1 \\
\hline 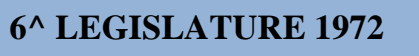 & 3,8 & 1,5 \\
\hline 7^ LEGISLATURE 1976 & 8,4 & 3,4 \\
\hline $8^{\wedge}$ LEGISLATURE 1979 & 8,4 & 3,4 \\
\hline 9^ LEGISLATURE 1983 & 7,9 & 4,9 \\
\hline 10^ LEGISLATURE 1987 & 12,6 & 6,7 \\
\hline 11^ LEGISLATURE 1992 & 7,9 & 9,0 \\
\hline 12^ LEGISLATURE 1994 & 15,4 & 8,6 \\
\hline 13^ LEGISLATURE 1996 & 9,5 & 7,9 \\
\hline 14^ LEGISLATURE 2001 & 11,5 & 8,1 \\
\hline 15^ LEGISLATURE 2006 & 17,3 & 14 \\
\hline 16^ LEGISLATURE 2008 & 21,27 & 18.3 \\
\hline MEDIA & 8.9 & 6.5 \\
\hline
\end{tabular}

Source:

http://www.istat.it/istat/eventi/2006/partecipazione_politica_2006/partecipazionepolitica.pdf

${ }^{3}$ Sources: Senate of the Republic; Chamber of Deputies, Prerogative Service and Immunity and InterParliamentary Union, Database Regional Parliamentary assemblies. 
Fig. 1. - Women Senators from $1^{\text {st }}(1948)$ to $16^{\text {th }}$ (2008) Legislature

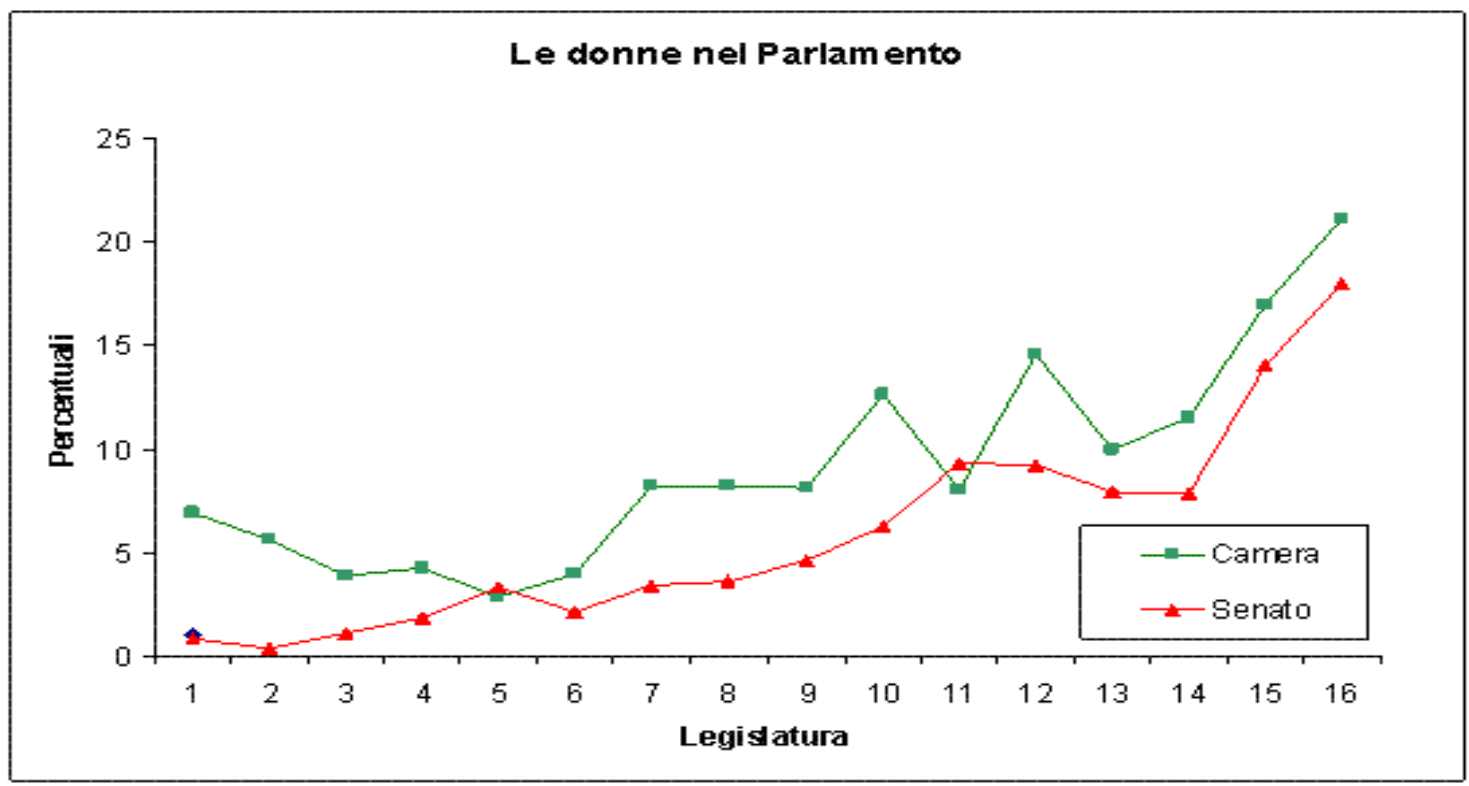

Source:http://www.istat.it/istat/eventi/2006/partecipazione_politica_2006/partecipazionepoli tica.pdf

As shown in the graph above, over the decades there has been a substantial increase in the number of female senators and deputies. However, this growth is not only due to greater political sensitivity towards female representation, interest in self-candidacy or implementation of constitutional provisions, but it is related to the intervention of "external" factors and "interior" legislative corrective measures. It is therefore an epiphenomenon determined by the effect of application of international regulations on equal opportunities (UN conventions, including CEDAW against gender discrimination) and the directives issued by the European Union, starting from equal treatment and remuneration.

But there are also other reasons. It is not, in fact, a case that the greatest surge in female presences since the post-war period, with $14.44 \%$ in the Chamber and $9.21 \%$ in the Senate, occurred in 1994, a year after the entry into force of the law No 81 of 25-3-1993, which admitted quotas or "reserved" places for female candidates. However, a subsequent ruling by the Constitutional Court had judged this as an unconstitutional law (No. 422, 1995) on basis of the 
principle of freedom, according to which every citizen can choose whether to vote or be voted, regardless of gender.

The so-called debate on "pink quotas" has then continued to this day, provoking countless polemics, ended with an unusual but understandable bipartisan coalition between male parliamentarians, united by gender solidarity and fear of losing the privileges acquired. But the commitment to promoting women's participation in political life is not limited to the regulatory side. Cultural action, information and training are essential in this matter.

A first step in this direction was made by starting in 17 universities in the central-southern area of the country a project called "Women, politics and institutions - Training courses for promotion of equal opportunities in decision-making and political centres". This is a training course for women with a high school diploma, aimed at promoting their affirmation and inclusion in political life and decision-making centres, both at national and local level, in elective assemblies, in Councils and Consultative Committees, where women are generally in a minority position.

At a local level, the female presence in Italy is decidedly consistent, especially when compared to data relating to Parliament; the number of women in the Regions and Provinces is growing moderately, while in municipalities there is a significant female participation. Consideration should be given to why women are more politically present at local level than at central level. It is increasingly clear that wherever women have embarked on a training path that would lead them to demanding professional and responsible outcomes, this could only happen by paying higher prices, significantly higher than men.

However, there is still no awareness that the participation of women in politics can bring that typically feminine pragmatism, concreteness and determination in pursuing objectives with a spirit of sacrifice and dedication to the common good. As the women - compared to men - are less worried in search for positions of power out of pure personal gratification, they constitute in fact the half of free beings. (Aristotle, 1955, p. 60)

The presence of women in politics, in an area still purely masculine, could therefore favour fundamental changes both at the methodological level and in the content of the debate.

A democracy is based on the dual citizenship of women and men, both subject to the right of citizenship and representation. Not a recovery quota for women, but a guarantee of 50\% of presence is to be considered with both male and female candidates composing alternately the electoral lists. And this is the other substantial aspect of the proposed law, because the politics 
among men and women is finally put back on the public level of confrontation and it is no longer forced into the private bottleneck of struggle between genders. Because there can be no effective policies for women without having the women themselves as protagonists of choices; because one can't have a promotion of empowerment "in the name" of women, but "with" the women (Donno, 2010: 148).

Having more women in elective assemblies, means being able to offer a style of government capable of interpreting at all levels different necessities and offering diversified responses to all men and women, with a more adherent representation of reality. Because no difference will ever be a value if the reality that surrounds us is described and interpreted with a single colour, a single glance, from a single gender. (Donno, 2010, p. 148)

\section{Italian Women and the European context}

In different surveys on political participation, at least relying on the chosen indicators, Italy appears to be the European country with the greatest difference between men and women: the gap decreases decidedly among the younger people, but it is still substantial. (Inglehart, 1988, p. 420422) The increasingly massive access to higher levels of scientific and professional training has been a factor of increasing emphasis on the quality of women's presence in society and the importance of contribution women can provide to civil development of the country. This has not happened without effort and without encountering obstacles. (Papa, 2010, p. 153)

In the EU countries, the gender composition of political representation is often more balanced than the situation in Italy. In the Anglo-Saxon countries, the "public" presence of women has a more distant tradition compared to Italy. It is therefore not surprising that in these countries, the female presence in politics is superior to the others. The increase in the number of women present in political institutions has been a consequence of the initiatives of individual governments, aimed at promoting their political participation. The EU, after a series of declarations about principle and non-binding generic opinions, invited the member countries to develop concrete projects that would remove the obstacles encountered by women in politics.

The presence of women in political representation in Italy is low in most international comparisons. In recent years, international statistics have shown a growing gap between men and women in terms of employment and management. In the European Union, Italy is along Greece the country marking the greatest difference between male and female unemployment. Moreover, 
among the industrialized countries, Italy is lagging behind the percentage of women in top positions in political, economic and social fields.

The Global Gender Gap Report 2010 has further highlighted this distance. In the Report, the gap between men and women is measured in terms of equal opportunities, referring to four main areas: participation and economic opportunities; educational level; political power; health and survival. Looking at 134 countries, the Report shows a clear deterioration of our country's position compared to the previous year. Italy has moved from the $72^{\text {nd }}$ to the $74^{\text {th }}$ place, overtaken by Malawi and Ghana. Only 3 out of 7 women have the opportunity to take on leadership positions. The comment of the Reports editors is lapidary in this regard: "Italy continues to be one of the lowest-ranking countries in the EU and deteriorates further over the last year." (World Economic Forum, Global Gender Gap, Report 2010, p. 21) Regarding the presence of women in the Parliament, Italy occupies the $54^{\text {th }}$ place out of a total of 188 countries internationally, as shown by the statistics produced by the Inter-Parliamentary Union, on basis of data provided by the respective Parliaments, within December 31, 2010.

In an international view, the female reality in Italy is still characterized by the "persistence and pervasiveness of the patriarchal attitude and stereotypes rooted in the roles and responsibilities of women and men in family and society". To build a society based on equal opportunities, it would be necessary to focus the spotlight on men and women, starting from these two distinct and indissoluble cores, for a future of substantial equality.

In spite of over thirty from the Convention for the Elimination of All Forms of Discrimination against Women, which called for the removal of discrimination that restricts women's participation in public and labour life, women are not yet fully represented in decision-making positions.

Italy's marginalization of women is particularly marked, especially in decision-making positions in politics. The comparison with the main European countries shows a gender imbalance in elective representation at national, regional and local levels. At the same time, recent surveys show a growing disaffection of women with respect to traditional forms of political participation. Women manifest also increasing levels of participation in the social life of local realities through a commitment that expresses the necessity to strengthen the women's presence in decision-making positions, as well as to introduce in politics a perspective which is sensitive to gender and diversity in institutions and in political choices. 


\section{Conclusions}

There are various causes of the low presence of women in politics. First of all, the lack of time penalizes women due to the difficulty in reconciling their requests with the family care and home management activities. The problem becomes more serious when added to the scarcity of economic means that also limits the possibility of undertaking expensive and costly electoral campaigns.

Women's position in the Italian society has been deeply affected by socio-cultural changes since the beginning of the 1970's (second-wave feminism). However, transformations in the structures of the society have not been always consistent with it. Political parties were slow to respond to the requests of civil society movements including women's movement. (Roselli, 2014, p. 8)

The lower political participation of women has multiple causes. For example, women are almost entirely responsible for family issues and therefore for social duties that make them less available for a political career. Women are also less easily accessing politics because they generally occupy less senior positions than men in professional life and are less represented in economic lobbies. As for the opportunities of profiling on political scene, they do not yet have models or a tradition to draw inspiration from. And finally, many women prefer to engage in extraparliamentary institutions or carry out voluntary activities in the social or ecclesial field.

But it is above all the perception of distance between their own world and that of politics that keeps women away from such activity: "Women emphasize the value of concreteness, of the necessity to measure proposals, to confront each other, to build, to work for objectives, and politics appears to them to be a self-referential space, in which powers and vetoes are exercised, that are neither clear nor objectives, neither the rules nor the places of expression". (Zajczyk, 2007, p. 69)

The temporal factor is also identified by Gelli as an element that makes it difficult for women to access the political dimension, in the sense that "there is no a history, there are missing models of action and interventions/changes on the social reality to which women individually and in group can refer to. The memory of a power, that is an exercise of politics, is lacking" (Gelli, 2009, p. 132) In identifying the factors that in other countries have hindered women's access to politics and institutions, Gelli, alongside the "Catholic religion with more or less direct influence on the model of femininity and the role of women in the family to the majority voting system", places the "delay in granting of suffrage" in the first place. 
We have seen that hitherto cultural prejudices have in fact relegated women to the family sphere or have caused them to be entrusted with roles borrowed from domestic life and of little strategic importance. To reverse this trend, we should start from a sort of education and awareness on equal opportunities for men and women. We need to start initiatives aimed at modifying a culture, in which man is still considered the protagonist of management of the republic and implement ways of sensitization to facilitate access to politics of that half of humanity that, as men, must have the same rights in the name of a more balanced representation and in compliance with the principles of democracy and equality.

The most difficult task is to promote a rising of awareness through a new culture that recognizes the values and indispensability of women's contribution to decision-making processes. It must be an action not only in favour of women, but also and above all aimed at women, so that they become aware of the role they must play in institutions. The great revolution consists above all in the way women think, in their courage to present themselves with their specificity instead of making the own old male models their own and masculinising their behaviour; in their abandoning scepticism and starting to become aware of their own qualities and potential with audacity, conviction, and with the ability to grasp new needs and facilitate change.

\section{References}

1. Aiston, J. M., \& Spence, J. (2010). Women, Education, and Agency, 1600-2000. New York: Routledge.

2. Aristotele. (1955) Politica e Costituzioni di Atene. in Viano C.A., (Eds). Torino: Utet.

3. Arslan, A. (1988) Ideologia e autorappresentazione. Donne intelettuali tra Ottocento e Novecento, in Buttafuoco, A. e Zancan, M. (Eds), Svelatamento. Sibilla Aleramo: una biografia intelettuale, Milano: Feltrinelli.

4. Bagnato, T. (2006) Il ruolo delle donne nella resistenza. Lotta partigiana e inclusione nei partiti, Instoria, 18, pp. 56-96.

5. Betty Friedan, B. (1963) La mistica della femminilità, Milano: Edizioni di Comunità.

6. Buttafuoco, A. (1992) Per un diritto. Coeducazione e identità femminile nell'emancipazionismo italiano tra ' 800 e '900, in Beseghi, E. \& Telmon, V. (Eds), Educazione al femminile: dalla parità alla differenza, Firenze: La nuova Italia. 
7. Cappiello, A. (1999) Infrangere il tetto di vetro. Quindici anni di politica per le donne, Roma: KOINè.

8. Castledine. L.J. \& Laughlin, A.K. (2011). Breaking the Wave: Women, Their Organizations, and Feminism, 1945-1985. New York: Routledge.De Leo, M. and Taricone, F. (1999), Quale politica per le donne, le donne in Italia. Diritti civili e politici. Napoli: Liguori editore..

9. De Martino, B. (1994) Le filosofe. Napoli: Liguori editore.

10. Donno, M. G. (2010) Cittadinanza duale e democrazia paritaria. Etiche e politiche di genere. Bari: Servizio Editoriale Universitario.

11. Gelli, B. (2009) Psicologia della differenza di genere. Soggettività femminili tra vecchi pregiudizi e nuova cultura. Milano: Franco Angeli.

12. Inglehart, R., (1988) La nuova partecipazione bella società post-industriali. Rivista Italiana di Scienze politica, 18(3), pp. 420-422.

13. ITALY. PRESIDENZA DEL CONSIGLIO DEI MINISTRI (1975) La donna italiana dalla Resistenza ad oggi.

14. ITALY. SENATO DELLA REPUBBLICA. (2010) Servizio prerogative e Immunità e Unione Interparlamentare.Man Ling, T. (2007). Rethinking the Personal and the Political: Feminist Activism and Civic Engagement. Hypatia: A Journal of Feminist Philosophy 22, no. 4.

15. Millet, K. (1979) La politica del sesso. Milano: Bompiani.

16. Morandini, G. (1980) La voce che è in lei. Antologia della narrativa italiana tra '800e '900. Milano: Bompiani.

17. Nicola, G. P. (1983) Donne e politica. Quale partecipazione? Roma: Città Nuova Editrici.

18. Papa, F. M. (2010) La questione della partecipazione politica delle donne. Una questione aperta della democrazia itiliana. Etiche e politiche di genere, 4, p.153.

19. Rosselli, A. (2014) The policy on gender equality in Italy. In-depth analysis. Brussels: European Union.

20. Santucci, F. (2004) Donne protagoniste. Firenze: Il Foglio.

21. Wollstonecraft, M. (1977) I diritti della donna. Roma: Editori Riuniti.

22. WORLD ECONOMIC FORUM (2010) Global Gender Gap Index. Avaible from: https://www.weforum.org/reports. 
23. Zajczyk, F. (2007) La resistibile ascesa delle donne in Italia. Stereotipi di genere e costruzione di nuove identità. Milano: Il Saggiatore. 